\title{
A comparative analysis of projected impacts of climate change on river runoff from global and catchment-scale hydrological models
}

\author{
S. N. Gosling ${ }^{1}$, R. G. Taylor ${ }^{2}$, N. W. Arnell ${ }^{3}$, and M. C. Todd ${ }^{4}$ \\ ${ }^{1}$ School of Geography, University of Nottingham, UK \\ ${ }^{2}$ Department of Geography, UCL, UK \\ ${ }^{3}$ Walker Institute for Climate System Research, University of Reading, UK \\ ${ }^{4}$ Department of Geography, University of Sussex, UK
}

Received: 24 August 2010 - Published in Hydrol. Earth Syst. Sci. Discuss.: 23 September 2010

Revised: 14 December 2010 - Accepted: 3 January 2011 - Published: 21 January 2011

\begin{abstract}
We present a comparative analysis of projected impacts of climate change on river runoff from two types of distributed hydrological model, a global hydrological model (GHM) and catchment-scale hydrological models (CHM). Analyses are conducted for six catchments that are global in coverage and feature strong contrasts in spatial scale as well as climatic and developmental conditions. These include the Liard (Canada), Mekong (SE Asia), Okavango (SW Africa), Rio Grande (Brazil), Xiangxi (China) and Harper's Brook (UK). A single GHM (Mac-PDM.09) is applied to all catchments whilst different CHMs are applied for each catchment. The CHMs include SLURP v. 12.2 (Liard), SLURP v. 12.7 (Mekong), Pitman (Okavango), MGB-IPH (Rio Grande), AV-SWAT-X 2005 (Xiangxi) and Cat-PDM (Harper's Brook). The CHMs typically simulate water resource impacts based on a more explicit representation of catchment water resources than that available from the GHM and the CHMs include river routing, whereas the GHM does not. Simulations of mean annual runoff, mean monthly runoff and high (Q5) and low (Q95) monthly runoff under baseline (1961-1990) and climate change scenarios are presented. We compare the simulated runoff response of each hydrological model to (1) prescribed increases in globalmean air temperature of $1.0,2.0,3.0,4.0,5.0$ and $6.0^{\circ} \mathrm{C}$ relative to baseline from the UKMO HadCM3 Global Climate Model (GCM) to explore response to different amounts of climate forcing, and (2) a prescribed increase in global-mean air temperature of $2.0^{\circ} \mathrm{C}$ relative to baseline for seven GCMs to explore response to climate model structural uncertainty.

We find that the differences in projected changes of mean annual runoff between the two types of hydrological model can be substantial for a given GCM (e.g. an absolute
\end{abstract}

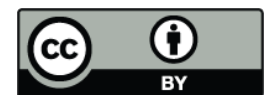

Correspondence to: S. N. Gosling (simon.gosling@nottingham.ac.uk)
GHM-CHM difference in mean annual runoff percentage change for UKMO HadCM $32{ }^{\circ} \mathrm{C}$ warming of up to $25 \%$ ), and they are generally larger for indicators of high and low monthly runoff. However, they are relatively small in comparison to the range of projections across the seven GCMs. Hence, for the six catchments and seven GCMs we considered, climate model structural uncertainty is greater than the uncertainty associated with the type of hydrological model applied. Moreover, shifts in the seasonal cycle of runoff with climate change are represented similarly by both hydrological models, although for some catchments the monthly timing of high and low flows differs. This implies that for studies that seek to quantify and assess the role of climate model uncertainty on catchment-scale runoff, it may be equally as feasible to apply a GHM (Mac-PDM.09 here) as it is to apply a CHM, especially when climate modelling uncertainty across the range of available GCMs is as large as it currently is. Whilst the GHM is able to represent the broad climate change signal that is represented by the CHMs, we find however, that for some catchments there are differences between GHMs and CHMs in mean annual runoff due to differences in potential evapotranspiration estimation methods, in the representation of the seasonality of runoff, and in the magnitude of changes in extreme (Q5, Q95) monthly runoff, all of which have implications for future water management issues.

\section{Introduction}

\subsection{Classification of hydrological models}

Numerically-based hydrological models can be classified as either deterministic or stochastic (Beven, 2001; Abbott and Refsgaard, 1996). Deterministic models permit a single outcome from a simulation with one set of inputs and parameter

Published by Copernicus Publications on behalf of the European Geosciences Union. 
values, whereas stochastic models allow for an element of randomness in the outcomes due to uncertainties associated with the input variables, boundary conditions or model parameters. With deterministic models, two main approaches to modelling may be adopted, the lumped approach or the distributed approach (Breuer et al., 2009; Beven, 2001; Abbott and Refsgaard, 1996). Lumped hydrological models consider the whole system (catchment, sub-catchment, aquifer, etc.) as a single unit and typically represent state variables, such as average storage in the saturated zone, as an average over the entire catchment. A limitation of the lumped approach is that the models are not able to consider the spatial diversity of hydrological processes over large spatial domains, associated with heterogeneity in land cover/use and soil properties, for example. In contrast, distributed hydrological models typically incorporate spatial variable datasets (e.g., land use, land and soil characteristics and forcing input) and discretize the catchment into sub-units (e.g. grid cells). As such, distributed models are able to provide a more representative description of catchment-scale processes than lumped models (Abbott and Refsgaard, 1996). Indeed, several studies show that distributed models demonstrate higher skill than lumped models in simulations of runoff (Refsgaard and Knudsen, 1996; Boyle et al. 2001; Carpenter and Georgakakos, 2006).

Distributed models feature a range of complexities. Fullydistributed models (e.g. MGB-IPOH, Collischonn et al., 2007) typically divide the catchment into a uniform grid and are the most complex but they are often criticized because an a priori estimation of model parameters is difficult (Breuer et al., 2009). Semi-distributed models with less complex spatial resolution simulate all hydrological processes within spatially non-explicit Hydrological Response Units (HRU); results for each HRU are lumped within sub-catchments and routed downstream. Examples include SWAT (Arnold et al., 1998) and SLURP (Kite, 1995). Furthermore, distributed models are applied at a range of spatial scales, from a few tens of meters grid cell resolution for small basins and urban areas (e.g. the DSHVM model, Cuo et al., 2008), to the size of medium-size sub-catchments using catchmentscale hydrological models (CHMs, e.g. the SLURP model, Thorne, 2010) and up to the global-scale with global hydrological models (GHMs, e.g. the WaterGAP model, Döll et al., 2003). The explicit representation of catchment water resources (e.g., soil water, groundwater, snow/ice, river channel losses) typically differ depending upon model scale. For instance, CHMs usually simulate water resource impacts based on a more explicit representation of catchment water resources than that available from GHMs.

\subsection{The opportunity for a novel comparison of a GHM with a CHM}

Whilst a variety of earlier studies have inter-compared distributed versus lumped model simulations (Carpenter and

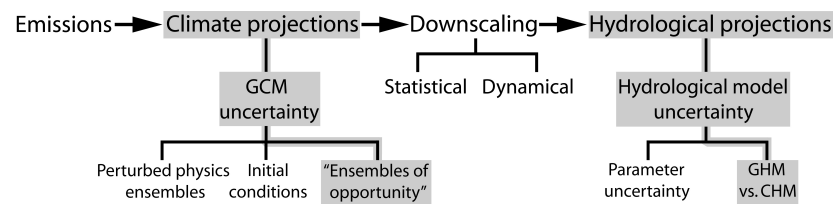

Fig. 1. The four stages of a climate change hydrological impact assessment and the inherent uncertainties. The shaded areas denote the uncertainties we considered in this analysis.

Georgakakos, 2006; Boyle et al., 2001; Refsgaard and Knudsen, 1996) or differences between several models that have been designed to operate at similar spatial scales (Jones et al., 2006), the comparison of distributed model simulations from a GHM with a CHM has not yet been explored. Furthermore, the opportunity exists to explore how these two types of model respond to consistent climate change forcing. The comparison is novel and significant because GHMs typically aggregate catchment-scale measures of water resources to calculate national, regional, or global-scale indicators of water resources (Arnell, 2004a; Alcamo et al., 2003). Such a comparison should demonstrate the potential feasibility of applying a GHM to evaluate catchment-scale indicators of water resources, which are usually assessed by CHMs.

\subsection{Uncertainties in climate change hydrological impact assessment}

Climate change will affect the global terrestrial hydrological system (Kundzewicz et al., 2007) and there is evidence that it has already responded to the observed warming over recent decades (Bates et al., 2008). The most common method for assessing the magnitude of this impact is to run a hydrological model driven by various climate projections from general circulation models (GCMs, i.e. global-scale climate models) as input forcing data (e.g. Gosling et al., 2010). The simulations of key hydrological indicators, such as river runoff, can then be used to assess the potential impact of climate change and to inform policy- and decision-making. However, there are a number of uncertainties associated with making such projections.

Figure 1 summarises the four main stages of performing a climate change hydrological impact assessment, which is broadly similar to other climate change impact sector assessments (Gosling et al., 2009). The first stage is to determine the greenhouse gas emissions scenarios with which the climate model (e.g. a GCM) will be driven with, in order to produce the climate change projections (the second stage).

GCMs typically represent the atmosphere, ocean, land surface, cryosphere, and biogeochemical processes, and solve the equations governing their evolution on a geographical grid covering the globe. Some processes are represented explicitly within GCMs, large-scale circulations for instance, while others are represented by simplified parameterisations. 

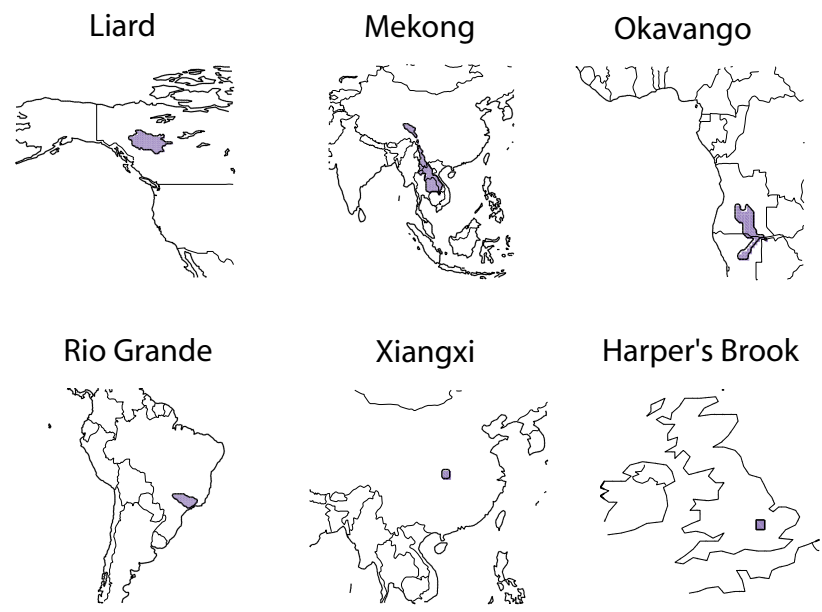

Fig. 2. Maps showing the $0.5^{\circ} \times 0.5^{\circ}$ model grid cells located within the catchments we investigated. The number of cells included within each catchment is shown in Table 1.

The use of these parameterisations is sometimes due to processes taking place on scales smaller than the typical grid size of a GCM (a horizontal resolution of between 250 and $600 \mathrm{~km}$ ) or sometimes to the current limited understanding of these processes. Different climate modelling institutions will use different plausible representations of the climate system, which is why climate projections for a single greenhouse gas emissions scenario will differ between modelling institutes. Two main methods can be used to sample this so called "climate model structural uncertainty". The first is to use a range of climate projections from ensembles of plausible GCMs, to produce an ensemble of impact projections for comparison. Such multi-model datasets are often described as "ensembles of opportunity", e.g. the World Climate Research Programme Third Coupled Model Intercomparison Project (WCRP CMIP3; Meehl et al., 2007). A second approach generates a "perturbed physics ensemble" (PPE) that introduces perturbations to the physical parameterisation schemes of a single climate model, leading to many plausible versions of the same underlying model. If sufficient computer power is available, then very large ensembles can be generated in this way. For example, Stainforth et al. (2005) ran an ensemble of 2578 simulations that sampled combinations of low, intermediate, and high values of 6 parameters. As well as climate model structural uncertainty, climate models are sensitive to the initial conditions with which the models are initialised, which adds a further level of uncertainty.

The third stage of a climate change hydrological impact assessment is to downscale the climate model output to a finer resolution, suitable for application to a hydrological model. Two approaches are typically available, statistical downscaling and dynamical downscaling. The former uses statistical relationships to convert the large-scale projections from a GCM to fine scales. Different statistical methods can be applied for the downscaling, which introduces uncertainty. The latter approach uses a dynamic model similar to a GCM to cover a region. The dynamic model is then forced at its lateral boundaries using results from the coarse scale GCM. The dynamic method is typically more computationally expensive but does not rely on the central assumption of most statistical downscaling, that the downscaling relationship derived for the present day will also hold in the future.

In the final stage, the downscaled climate data is applied to a hydrological model. Uncertainty at this stage can arise from the application of different hydrological models, e.g. CHMs and GHMs (similar in essence to the uncertainty that can be sampled from a GCM ensemble of opportunity), and from different parameters sets and perturbations within a given hydrological model, i.e. parameter uncertainty (similar in essence to the uncertainty that can be sampled from a GCM PPE).

For six catchments, we compare the simulated runoff response of a GHM and CHM to projected future climate associated with (1) several prescribed increases in global-mean temperature from a single GCM to explore simulated response to different amounts of climate forcing, and (2) a prescribed increase in global-mean temperature of $2.0^{\circ} \mathrm{C}$ for seven GCMs to explore response to climate model structural uncertainty. The main sources of uncertainty sampled by this methodological framework are shaded in Fig. 1. Note that emissions uncertainty and downscaling uncertainty are not sampled, i.e. they are held constant, and nor do we consider GCM perturbed physics or hydrological model parameter uncertainty.

\section{Data and methods}

In this section, we first describe the GHM and CHMs applied in this study. We then describe the climate data that was used to drive the hydrological models. Finally, we describe the hydrological indicators calculated for the comparison.

\subsection{River catchments and hydrological models}

The six catchments we considered for the comparison are global in coverage and feature strong contrasts in spatial scale as well as climatic and developmental conditions. They include: the Liard (Canada), Mekong (SE Asia), Okavango (SW Africa), Rio Grande (Brazil), Xiangxi (China) and Harper's Brook (UK) - see Fig. 2. Catchments were selected where international researchers had already established locally calibrated, distributed CHMs derived from previous and on-going research projects (Todd et al., 2010). The CHMs are described in detail in each of the papers in this issue and a summary is provided in Table 1 . Note that a different, single CHM was applied to each catchment respectively.

All the CHMs had already been calibrated typically using local gauge networks. For each catchment, the CHM 
Table 1. List of the catchments and their characteristics included in this study and the CHMs applied to each respective catchment. References for the re-calibrated version of each CHM applied in this study are given in the far right column, next to the the Nash-Sutcliffe model efficiency coefficients $(E)$ (Nash and Sutcliffe, 1970) that were calculated in validation exercises presented by those studies. $n$ denotes the number of $0.5^{\circ} \times 0.5^{\circ}$ model grid cells located within each catchment.

\begin{tabular}{|c|c|c|c|c|c|c|}
\hline Catchment & $\begin{array}{l}\text { Area } \\
\left(\mathrm{km}^{2}\right)\end{array}$ & $n$ & $\begin{array}{l}\text { Catchment } \\
\text { Hydrological Model }\end{array}$ & $\begin{array}{l}\text { Climatic } \\
\text { zone(s) }\end{array}$ & $\mathrm{E}$ & $\begin{array}{l}\text { Reference in } \\
\text { this issue }\end{array}$ \\
\hline $\begin{array}{l}\text { Liard (a tributary of } \\
\text { the MacKenzie river, } \\
\text { Canada) }\end{array}$ & 275000 & 164 & $\begin{array}{l}\text { SLURP (v. 12.2) } \\
\text { semi-distributed } \\
35 \text { sub-basins } \\
\text { (Kite et al., 1994) }\end{array}$ & $\begin{array}{l}\text { Arctic and } \\
\text { sub-Arctic }\end{array}$ & 0.75 & Thorne (2010) \\
\hline $\begin{array}{l}\text { Mekong } \\
\text { (Southeast Asia) }\end{array}$ & 569410 & 192 & $\begin{array}{l}\text { SLURP (v. 12.7) } \\
\text { semi-distributed } \\
13 \text { sub-basins } \\
\text { (Kite, } 1995)\end{array}$ & $\begin{array}{l}\text { high-altitude } \\
\text { sub-tropical, } \\
\text { humid tropical }\end{array}$ & $\begin{array}{l}0.89,0.78,0.44 \\
\text { (three gauging stations) }\end{array}$ & Kingston et al. (2010) \\
\hline $\begin{array}{l}\text { Okavango } \\
\text { (south-west Africa) }\end{array}$ & 226256 & 80 & $\begin{array}{l}\text { Pitman } \\
\text { semi-distributed } \\
14 \text { sub-basins } \\
\text { (Hughes et al., 2006) }\end{array}$ & $\begin{array}{l}\text { humid and } \\
\text { semi-arid tropical }\end{array}$ & $\begin{array}{l}0.11-0.83 \\
\text { (range across } 14 \\
\text { gauging stations) }\end{array}$ & Hughes et al. (2010) \\
\hline $\begin{array}{l}\text { Rio Grande } \\
\text { (a tributary of } \\
\text { the Parana river, Brazil) }\end{array}$ & 145000 & 75 & $\begin{array}{l}\text { MGB-IPH (VIC) } \\
\text { distributed } \\
\text { (Collischonn et al., 2007) }\end{array}$ & humid tropical & 0.69 & Nóbrega et al. (2010) \\
\hline $\begin{array}{l}\text { Xiangxi (a tributary of } \\
\text { the Yangzte river, China) }\end{array}$ & 3099 & 9 & $\begin{array}{l}\text { AV-SWAT-X } 2005 \\
\text { semi-distributed } \\
\text { (Arnold et al., 1998) }\end{array}$ & humid sub-tropical & 0.56 & Xu et al. (2010) \\
\hline $\begin{array}{l}\text { Harper's Brook } \\
\text { (a tributary of } \\
\text { the Nene river, UK) }\end{array}$ & 74 & 1 & $\begin{array}{l}\text { Cat-PDM } \\
\text { distributed } \\
\text { (Arnell, 2003b; Arnell, 2004b) }\end{array}$ & humid, temperate & 0.58 & Arnell (2010) \\
\hline
\end{tabular}

was re-calibrated for use with gridded $\left(0.5^{\circ} \times 0.5^{\circ}\right)$ climate data from the CRU TS 3.0 dataset (Mitchell and Jones, 2005) for the period 1961-1990. This dataset was the baseline for all analyses presented here and for the papers listed in Table 1. Importantly, the climate change scenarios (described in Sect. 2.2.) are compatible with the baseline (Todd et al., 2010), which is why each CHM was re-calibrated against the baseline. This process is described in each of the individual papers in this issue, listed in Table 1. A summary of the Nash-Sutcliffe model efficiency coefficients $(E)$ (Nash and Sutcliffe, 1970) that were calculated in validation exercises presented by each paper is also presented in Table 1. According to the classifcation scheme of Henriksen et al. (2008), the CHMs generally performed "fair" to "excellent", although for a very small number of gauging stations in the Okavango and Mekong, the performance was "poor" (see Hughes et al., 2010, and Kingston et al., 2010, for more details).

We applied the Mac-PDM.09 ("Mac" for "macro-scale" and "PDM" for "probability distributed moisture model") GHM in this study. Detailed descriptions of Mac-PDM.09 which simulates runoff across the world at a spatial resolution of $0.5^{\circ} \times 0.5^{\circ}$, are provided by Gosling and Arnell (2010) and Arnell (1999, 2003a). The model has been shown to perform as well as other GHMs in a recent GHM intermodel comparison exercise (Haddeland et al., 2011). In brief, Mac-PDM.09 calculates the water balance in each of
65000 land surface $0.5^{\circ} \times 0.5^{\circ}$ cells on a daily basis, treating each cell as an independent catchment. It is implicit in the model formulation that these cells are equivalent to mediumsized catchment areas (i.e., 100 to $5000 \mathrm{~km}^{2}$ ). River runoff is generated from precipitation falling on the portion of the cell that is saturated, and by drainage from water stored in the soil. A basin-specific calibration of Mac-PDM.09 was not performed; instead, the model was calibrated by 'tuning' it to help set parameter values. This involved tests of precipitation datasets and potential evaporation calculations and was done against long-term average runoff and long-term average within-year runoff patterns for a small number of major river basins and for a large number of small basins (see Arnell, 1999). Model parameters describing soil and vegetation characteristics are taken from spatial land cover data sets (de Fries et al., 1998; FAO, 1995). For comparison with the CHMs, river runoff was simply aggregated for all grid cells within the boundaries of the river catchments applicable to each CHM respectively as shown in Fig. 2. Hereafter, we refer to Mac-PDM.09 as the GHM. The GHM simulations were performed on the University of Reading Campus Grid by high-throughput computing (Gosling et al., 2010). 
Table 2. GCMs that were pattern-scaled by ClimGen and applied in this study.

\begin{tabular}{ll}
\hline GCM & Climate modelling centre and location \\
\hline UKMO HadCM3 & Hadley Centre for Climate Prediction and Research (UK) \\
CCCMA CGCM3.1 & Canadian Centre for Climate Modelling and Analysis (Canada) \\
IPSL CM4 & Institut Pierre Simon Laplace (France) \\
ECHAM5 & Max Planck Institute for Meteorology (Germany) \\
NCAR CCSM3 & National Centre for Atmospheric Research (USA) \\
UKMO HadGEM1 & Hadley Centre for Climate Prediction and Research (UK) \\
CSIRO MK3.0 & CSIRO Atmospheric Research (Australia) \\
\hline
\end{tabular}

\subsection{Climate data}

To facilitate the model comparison, consistent climate change forcing data were applied to the CHMs and GHM respectively. Monthly meteorological variables for the presentday climate - hereafter referred to as the baseline - were obtained from the gridded $\left(0.5^{\circ} \times 0.5^{\circ}\right)$ CRU TS 3.0 data set (Mitchell and Jones, 2005) for the period 1961-1990. Because the spatial resolution of climate change scenarios derived from GCMs is coarse compared to that of the hydrological processes simulated by GHMs and CHMs, climate data needed to be downscaled to a finer resolution. For example, the UK is covered by only 4 land cells and 2 ocean cells within the UKMO HadCM3 GCM. To this end, the climate change scenarios applied to the GHM and CHMs were generated using ClimGen, a spatial climate scenario generator that uses the pattern-scaling approach (Mitchell, 2003) to generate spatial climate change information for a given globalmean temperature change from the baseline and a given GCM. ClimGen includes a statistical downscaling algorithm that calculates climate change scenarios at $0.5^{\circ} \times 0.5^{\circ}$ resolution, taking account of higher resolution surface variability in doing so. A detailed description of the pattern-scaling technique applied by ClimGen is given by Todd et al. (2010).

To explore the effect of various degrees of global-mean warming on simulated runoff, climate change patterns for the UKMO HadCM3 GCM associated with prescribed increases in global-mean temperature of 1.0, 2.0, 3.0, 4.0, 5.0 and $6.0^{\circ} \mathrm{C}$ relative to the baseline were used. Also, to explore the effects of climate model structural uncertainty on simulated runoff, climate change patterns from seven GCMs included in the Coupled Model Intercomparison Project (CMIP3) archive (Meehl et al., 2007) associated with a prescribed increase in global-mean temperature of $2.0^{\circ} \mathrm{C}$ relative to the baseline were used - see Table 2 . The prior uncertainty from climate model structural uncertainty could be reduced by comparing the GCM simulations of baseline climate with observations (e.g. Gleckler et al., 2008) but the calculation of single indices of model performance can be misleading because it hides a more complex picture of the relative merits of different GCMs (see Arnell
(2010) for a more detailed discussion). Therefore all seven GCMs are assumed to be equally credible in this analysis.

ClimGen generates 30-year long monthly timeseries of forcing data for a given GCM and prescribed increase in global-mean temperature (e.g. UKMO HadCM3 $2.0^{\circ} \mathrm{C}$ ). This means that the 30-year long climate change scenarios for a given GCM are representative of a world that is warmer from baseline by a prescribed temperature, but they are not assigned a specific time period in years, which is arbitrary. Therefore the runoff simulations are also presented for arbitrary 30-year periods, representative of worlds where global-mean temperature is a prescribed amount warmer than baseline $\left(1.0,2.0,3.0^{\circ} \mathrm{C}\right.$ etc.). Most of the $\mathrm{CHMs}$ and the GHM required daily forcing data. Therefore a weather generator was applied to create daily data from monthly data. Detailed descriptions of the generator are provided by Todd et al. (2010).

\subsection{Hydrological indicators}

To investigate GHM-CHM differences in simulated runoff we calculated three indicators of hydrological performance for each CHM and GHM simulation respectively; (1) mean annual runoff, (2) mean monthly runoff and (3) high and low monthly runoff, expressed as Q5 and Q95 respectively, where for example, Q5 is the monthly runoff exceeded only $5 \%$ of the time, and thus high. To facilitate model comparisons, we express the mean monthly runoff as percentages of the simulated mean annual total runoff.

\section{Results}

\subsection{Precipitation changes}

Precipitation is the main driver of runoff (Chiew et al., 2009) so it is important to understand the magnitude by which it changes in each of the climate change scenarios we considered. Figure 3 shows the percentage change from baseline in total-annual precipitation for UKMO HadCM3 prescribed warming of $1-6^{\circ} \mathrm{C}$, for each catchment. The greatest changes in precipitation are observed for the Liard (around 

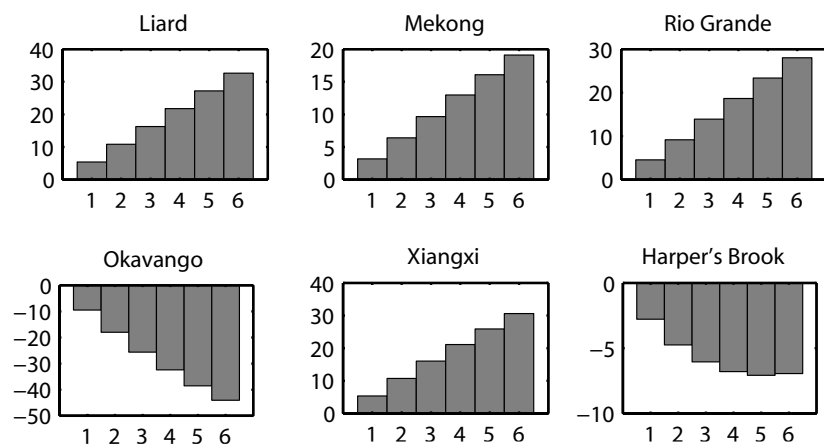

Fig. 3. Change in total-annual precipitation relative to baseline (vertical axis; \%) for UKMO HadCM3 prescribed warming of $1-6^{\circ} \mathrm{C}$ (horizontal axis), for each catchment.

$+33 \%$ with $6^{\circ} \mathrm{C}$ prescribed warming), Xiangxi (around $+31 \%$ with $6^{\circ} \mathrm{C}$ prescribed warming) and Okavango (around $-44 \%$ with $6^{\circ} \mathrm{C}$ prescribed warming). Harper's Brook is associated with a small change in precipitation with $6^{\circ} \mathrm{C}$ prescribed warming $(-7 \%)$. Analyses in Sect. 3.2. demonstrate how the simulated changes in precipitation from each prescribed increase in global-mean air temperature are realised in changes in runoff.

Figure 4 shows the percentage change from baseline in total annual precipitation projected by seven GCMs for a prescribed increase in global-mean air temperature of $2{ }^{\circ} \mathrm{C}$, for each catchment. Whilst all GCMs simulate increases in precipitation with climate change for the Liard, there is not consensus in the sign of precipitation change across the seven GCMs for the remaining catchments. For instance, with the Mekong, four GCMs simulate increases in precipitation with climate change and three GCMs simulate decreases. It could be argued that this precludes a hydrological analysis using all seven GCMs. However, given the large dependence of runoff on precipitation (Chiew et al., 2009) and that complex nonlinear interactions are common between climate forcing and runoff (Majone et al., 2010), it is important to demonstrate how the uncertainty in the projections of precipitation across GCMs translates into runoff projections. Moreover, the consequent uncertainty across runoff simulations could have important implications for water resources management. Analyses in Section 3.3. demonstrate how the simulated changes in precipitation from each GCM are realised in changes in runoff.

\subsection{Hydrological model responses to different amounts of forcing projected by UKMO HadCM3}

\subsubsection{Mean annual river flow}

Figure 5 shows the GHM and CHM changes in simulated mean annual runoff relative to baseline for UKMO HadCM3 prescribed warming of $1-6^{\circ} \mathrm{C}$. The GHM and CHMs simulate increased runoff with global-mean warming for the
Liard, Rio Grande and Xiangxi catchments. There is also agreement between the CHM and GHM that runoff decreases with global warming for the Okavango. The absolute GHMCHM differences in mean annual runoff percentage change for $2{ }^{\circ} \mathrm{C}$ warming are $12 \%$ (Liard), $9 \%$ (Mekong), $1 \%$ (Rio Grande), 6\% (Okavango), 10\% (Xiangxi) and 25\% (Harper's Brook). Even under large increases in global mean air temperature $\left(>4{ }^{\circ} \mathrm{C}\right)$ the GHM-CHM differences are relatively small for the Rio Grande $(<10 \%)$ and Okavango $(<20 \%)$ but the GHM estimates a substantially greater change in runoff relative to the CHM for the Liard $(>20 \%)$ and underestimates it for the Xiangxi $(>30 \%)$. There are stark differences in simulated annual runoff between the CHM and GHM for the Mekong and Harper's Brook catchments. With the Mekong, the GHM simulates a largely linear relationship between global-mean temperature and runoff, whilst the CHM simulates no major change from baseline. With Harper's Brook, the GHM simulates steady decreases in runoff with global warming of up to $-40 \%$, whereas the CHM simulates steady increases of up to $+20 \%$.

\subsubsection{The seasonal cycle}

Figure 6 shows the mean monthly runoff (expressed as a percentage of the annual total), for the baseline conditions and projected using climate fields from the UKMO HadCM3 $2{ }^{\circ} \mathrm{C}$ prescribed warming scenario, simulated by the GHM and CHMs. First, it is clear that for most catchments, especially those in the tropics, the amplitude of the seasonal cycle as simulated by the GHM is much greater than that simulated by the CHM. The CHMs were calibrated locally and so the simulated seasonal cycle is close to the observed seasonal cycle (see papers listed in Table 1). Hence the GHM tends to overestimate the seasonal cycle. The GHM and CHM simulate peak (Q5) and low (Q95) runoff as occurring in identical months for the Mekong and Harper's Brook. However, there is a tendency for the GHM to simulate the month of lowest runoff 1-2 months earlier than the CHM for the Rio Grande (August for GHM and September for CHM) and Okavango (September for GHM and November for CHM). Peak runoff is also simulated by the GHM one month earlier than the CHM for the Liard (May for the GHM and June for the CHM).

For the Rio Grande and Okavango, monthly runoff as a proportion of the annual total remains relatively unaltered with global warming; even up to $6^{\circ} \mathrm{C}$ the absolute difference in monthly runoff as a percentage of the annual total is small $(<3 \%)$ for any given month. However, climate change affects this proportion in the other catchments. For instance, with the Liard, the GHM and CHM consistently show an increase in springtime runoff with climate change $(>10 \%$ in April with the GHM and $>5 \%$ in May with the CHM). There are subtle GHM-CHM differences for the Mekong; July-September proportional runoff decreases with climate change for both hydrological models (by up to $3 \%$ of the 

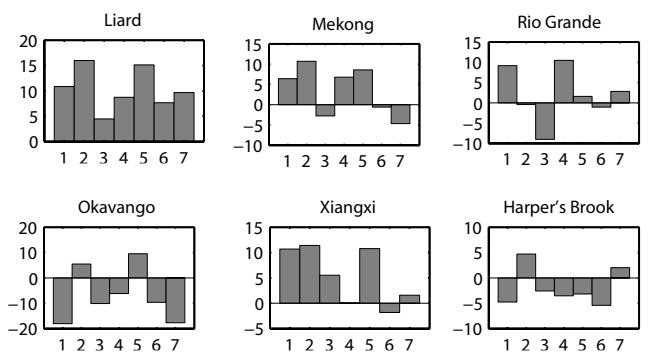

$1=$ UKMO HadCM3 $2=$ CCCMA CGCM
$3=$ IPSL CM4 $4=$ MPI ECHAM $5=$ NCAR CCSM3 $6=$ UKMO HadGEM
$7=$ CSIRO MK3.0

Fig. 4. Change in total-annual precipitation relative to baseline (vertical axis; \%) for for the $7 \mathrm{GCMs}$ under $2{ }^{\circ} \mathrm{C}$ prescribed warming (horizontal axis), for each catchment.
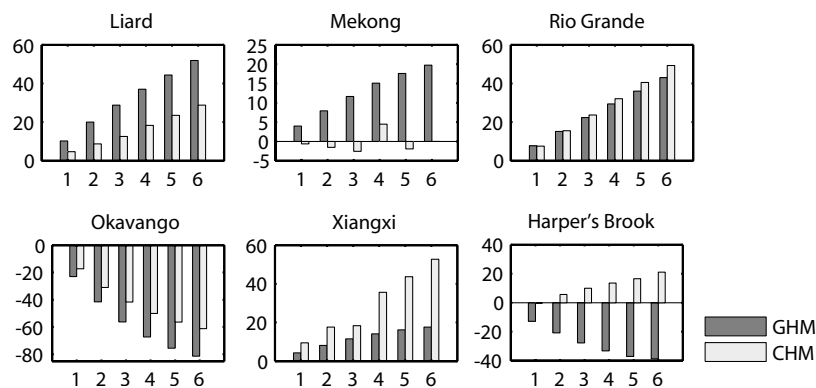

Fig. 5. Change in mean annual runoff relative to baseline (vertical axis; \%) for the 6 prescribed warming temperatures (horizontal axis), as simulated by the GHM and CHM respectively, for each catchment.

annual total) but April-June runoff increases relative to baseline using the CHM (up to $3 \%$ of the annual total), whereas as it remains almost unchanged from the baseline using the GHM. With the Xiangxi, the GHM shows much greater decreases in proportional summer runoff (up to $5 \%$ of the annual total) with global warming compared with smaller decreases simulated by the CHM ( $<2 \%$ of the annual total). However, the GHM and CHM are consistent in showing a shift of the peak runoff season from summer (July-August) to autumn (September-October) with climate change. For Harper's Brook, global warming induces a slight strengthening of the seasonal cycle, which even under baseline climate is more pronounced with the CHM than the GHM. For example, under $6^{\circ} \mathrm{C}$ warming the CHM simulates that January runoff presents $23 \%$ of the mean annual total runoff ( $16 \%$ for baseline) whilst the GHM simulates $17 \%$ of the total $(11 \%$ for baseline).

\subsubsection{Peak high and low monthly river flows}

Figure 7 shows the percentage change from simulated baseline in Q5 (high flow) and Q95 (low flow) monthly runoff under six degrees of prescribed global warming for each catchment and the GHM and CHM respectively. The GHM and $\mathrm{CHM}$ are consistent in showing an increase in the magnitude
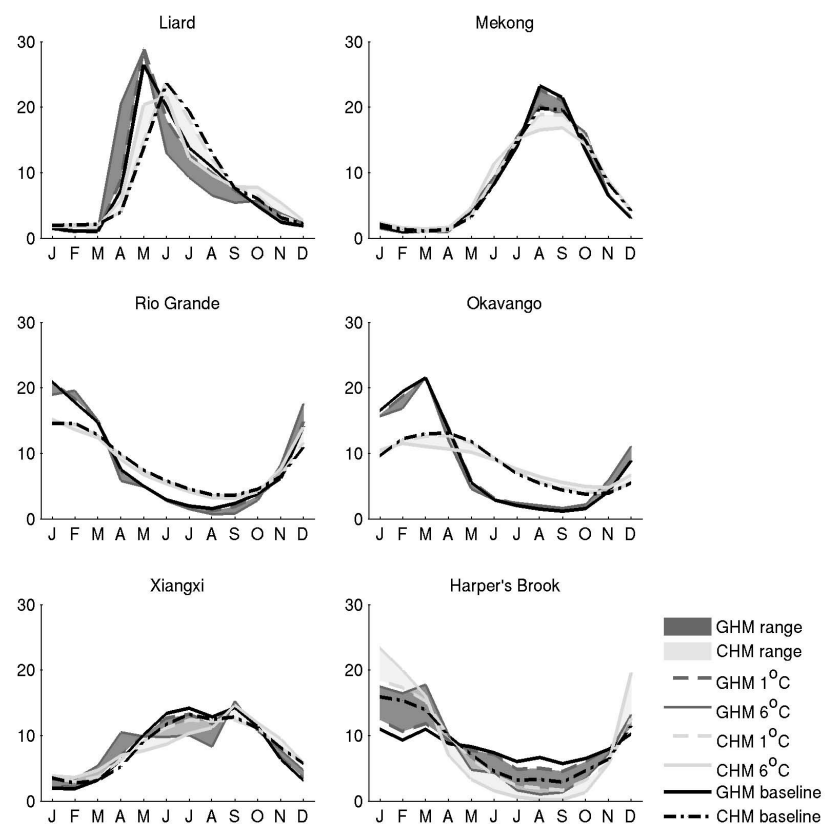

Fig. 6. Mean-monthly runoff, expressed as a percentage of the mean annual total runoff, simulated by the GHM and CHM respectively, for the baseline (black lines) and UKMO HadCM3 prescribed warming of $1^{\circ} \mathrm{C}$ and $6^{\circ} \mathrm{C}$. The range in simulated runoff between $1^{\circ} \mathrm{C}$ and $6^{\circ} \mathrm{C}$ prescribed warming is shaded.

of the change with the magnitude of global warming for all catchments, although there are differences between the GHM and CHMs in the sign of change in some cases such as the Mekong (Q5), Harper's Brook (Q5) and Rio Grande (Q95).

The sign and magnitude of projected changes to high and low flows and the sensitivity to degree of global warming (with the UKMO HadCM3 driving fields) is generally similar to that for mean annual flow (Fig. 5), with some notable exceptions. For the Mekong Q95 increases are smaller than those for mean annual flow; for the Rio Grande Q95 decreases with increasing global warming under the GHM simulations. With some catchments, the projected changes in low flows are high, such as with the Xiangxi, where the GHM and CHM simulate changes of $+75 \%$ and $+95 \%$ in Q95 relative to baseline with $6{ }^{\circ} \mathrm{C}$ prescribed warming. Even under large increases in global mean air temperature $\left(>4^{\circ} \mathrm{C}\right)$ absolute differences in simulated percentage changes between GHM and CHM are relatively small $(<20 \%)$ for some catchments (e.g. Q95 for the Xiangxi, Q5 for the Rio Grande) whereas for other catchments, the differences are substantial ( $>30 \%$; Q5 for the Xiangxi and Liard).

The GHM-CHM differences in simulated changes in extreme flows can be substantially greater than they are for changes in mean annual runoff. For instance, comparing Fig. 5 with Fig. 7 , for each catchment, with $2{ }^{\circ} \mathrm{C}$ warming, the GHM-CHM differences in mean annual runoff (Q5 and Q95 differences respectively in parenthesis) are $12 \%(14 \%$, 

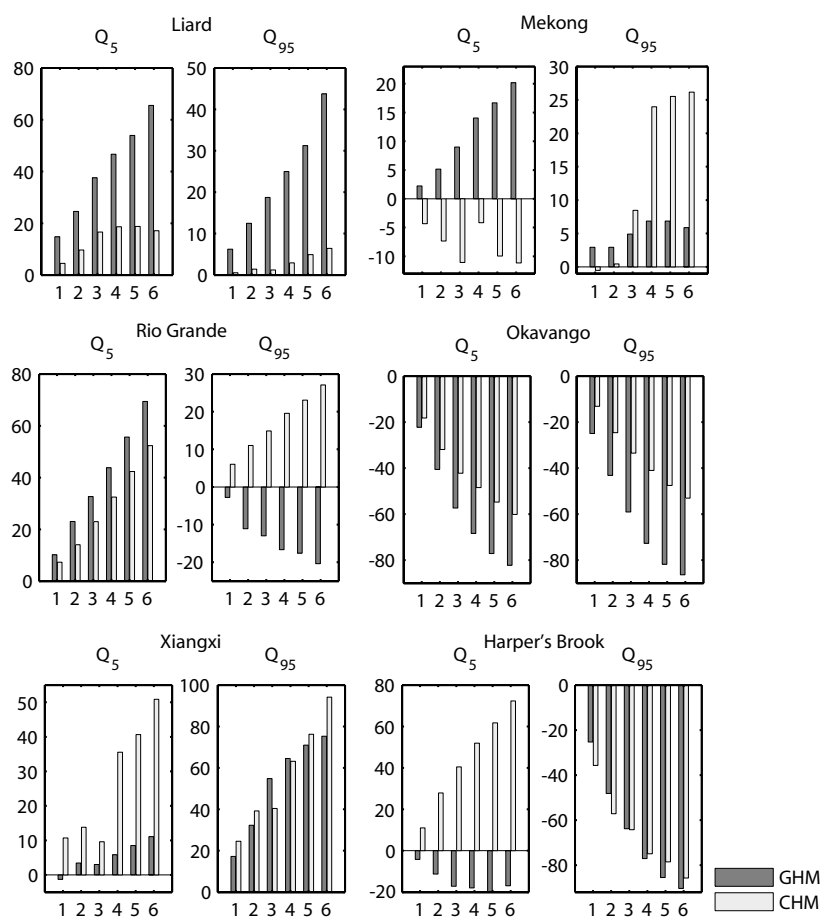

Fig. 7. Percentage change from baseline in GHM- and CHMsimulated Q5 and Q95 monthly runoff (vertical axis) with UKMO HadCM3 prescribed warming of $1-6^{\circ} \mathrm{C}$ (horizontal axis), for each catchment.

10\%; Liard), $9 \%$ (12\%, 3\%; Mekong), 1\% (9\%, 22\%; Rio Grande), $6 \%$ (7\%, 20\%; Okavango), 10\% (11\%, 5\%; Xiangxi) and $25 \%$ (38\%, 6\%; Harper's Brook).

\subsection{Hydrological model responses to climate modelling uncertainty}

\subsubsection{Mean annual river flow}

Figure 8 shows the GHM and CHM changes in simulated mean annual runoff relative to baseline for prescribed global warming of $2{ }^{\circ} \mathrm{C}$ for seven GCMs. There are two important observations to make. Firstly, there is little overall consensus in the sign of runoff change, be it an increase or decrease, across all seven GCMs for any of the catchments. For instance, with the Rio Grande, the CHM and GHM are consistent in showing decreases in runoff with climate change for three GCMs - CCCMA CGCM3.1 ( $-3 \%$ and $-3 \%$ [GHM and CHM respectively]), IPSL CM4 (-29\% and $-19 \%)$ and UKMO HadGEM1 $(-10 \%$ and $-1 \%)$ - but for four GCMs the CHM and GHM simulate increases in runoff - UKMO HadCM3 $(+15 \%$ and $+16 \%)$, MPI ECHAM5 $(+20 \%$ and $+18 \%)$, NCAR CCSM3 $(+1 \%$ and $+3 \%)$ and CSIRO MK3.0 $(+3 \%$ and $+7 \%)$. Projected differences between GCMs may be large. For example, NCAR CCSM3 driving climate data simulates a $+26 \%$ and $+29 \%$ change in runoff for the Oka-
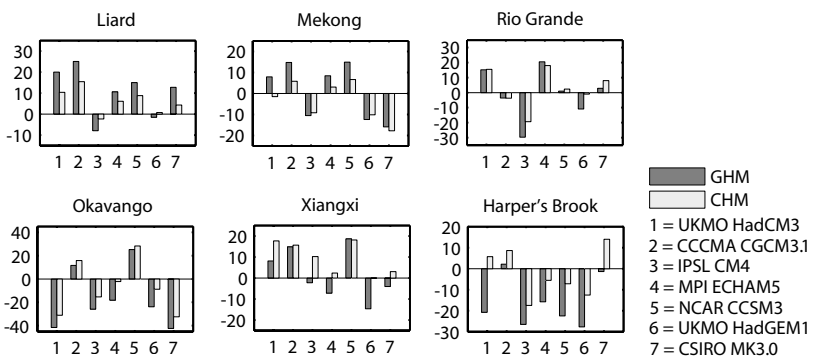

Fig. 8. Change in mean annual runoff relative to baseline (vertical axis; \%) for the $7 \mathrm{GCMs}$ under $2{ }^{\circ} \mathrm{C}$ prescribed warming (horizontal axis), as simulated by the GHM and CHM respectively, for each catchment.

vango (using the GHM and CHM respectively) and UKMO HadCM3 forcing simulates changes of $-40 \%$ and $-30 \%$ (using the GHM and CHM respectively). The greatest absolute differences in the percentage changes from baseline between any two GCMs with $2{ }^{\circ} \mathrm{C}$ prescribed warming for the GHM (CHM in parenthesis) for each catchment respectively are $28 \%$ (17\%; Liard), 30\% (23\%; Mekong), $48 \%$ (36\%; Rio Grande), 62\% (58\%; Okavango), 34\% (15\%; Xiangxi) and $30 \%$ (31\%; Harper's Brook). Only for the Xiangxi and Liard catchments do most of the simulations show a consistent (increased runoff) signal across most of the GCMs (see Todd et al. (2010) for further discussion of this).

Secondly, for a given GCM, the GHM and CHM are generally consistent in simulating the same sign of runoff change relative to baseline. This is true where the simulated changes in runoff are greater than $\pm 10 \%$. For cases where projected runoff changes are small $(<10 \%)$, the CHM and GHM may simulate runoff changes that are different in sign (e.g. Liard with UKMO HadGEM1 forcing and Xiangxi with MPI ECHAM 5 forcing). The one exception to this is Harper's Brook with UKMO HadCM3 and CSIRO MK3.0 forcing. Generally, the differences in projected changes to mean annual runoff between the two types of hydrological model are relatively small, in comparison to the range of projections across GCMs. In some cases, the difference in the absolute magnitude of the projected percentage change between the GHM and CHM may be as small as $1 \%$ (e.g. Rio Grande with UKMO HadCM3 forcing and Xiangxi with NCAR CCSM3 forcing).

\subsubsection{The seasonal cycle}

Figure 9 shows the mean monthly runoff for each catchment when the GHM and CHM are forced with the seven GCMs under a $2{ }^{\circ} \mathrm{C}$ rise in global mean air temperature; the ensemble mean, calculated from the mean of the seven projections, is also displayed for the GHM and CHM respectively, with the inter-GCM range of projections shaded. For the Okavango and Rio Grande catchments, the inter-GCM range is relatively small, compared to that for other catchments 

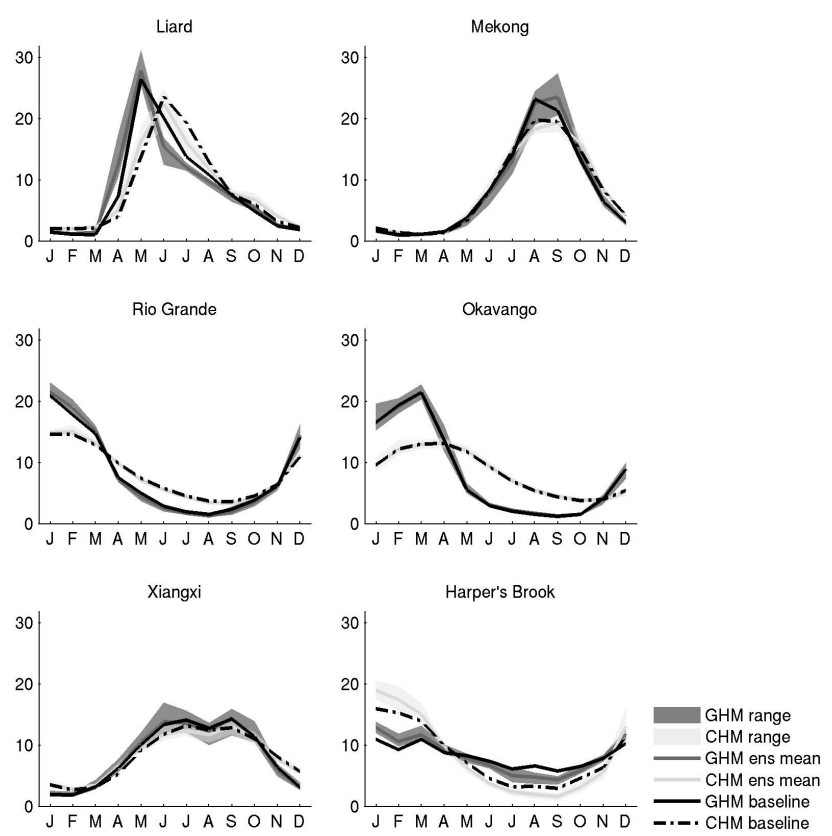

Fig. 9. Baseline and projected mean-monthly runoff simulated by the GHM and CHM respectively (expressed as a percentage of the mean annual total runoff) when they are forced by 7 GCMs under $2{ }^{\circ} \mathrm{C}$ prescribed warming, for each catchment. The light grey and dark grey lines show the ensemble mean across the 7 GCMs for the CHM and GHM respectively, with the shaded region denoting the inter-GCM range.

and the ensemble mean is very close to baseline. However, note that to aid hydrological model comparisons, Fig. 9 displays the mean monthly runoff as a percentage of the mean annual-total runoff - if the absolute values are plotted, the inter-GCM range would appear larger, similar to what is displayed in Fig. 9. There is consistency across GCMs in important changes in the seasonal cycle of runoff to a $2{ }^{\circ} \mathrm{C}$ prescribed increase in global-mean air temperature. For instance, an increase relative to baseline in springtime runoff for the Liard is represented by all seven GCMs, and so is a shift in peak runoff season from summer (July-August) to autumn (September-October) for the Xiangxi. Also, the GCMs suggest a move in the month of peak runoff from August to September with $2{ }^{\circ} \mathrm{C}$ prescribed warming for the Mekong.

\subsubsection{Peak high and low monthly river flows}

Figure 10 shows the percentage change from baseline in Q5 and Q95 monthly runoff (vertical axis) for the 7 GCMs with $2{ }^{\circ} \mathrm{C}$ prescribed warming simulated by the GHM and CHM respectively, for each catchment. Two observations, which are consistent across the six catchments, are noteworthy. Firstly, for a given GCM, the GHM and CHM tend to agree in the sign of simulated change for high and low flows respectively. In some cases, the difference between the GHM and
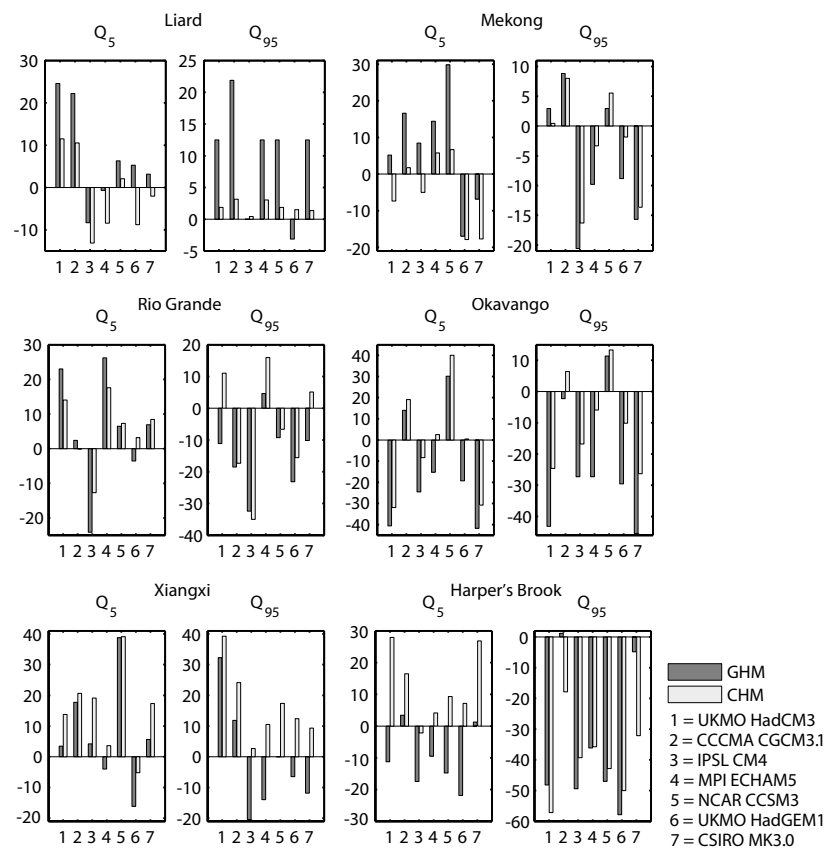

Fig. 10. Percentage change from baseline in Q5 and Q95 monthly runoff (vertical axis) for the $7 \mathrm{GCMs}$ (horizontal axis) under $2{ }^{\circ} \mathrm{C}$ prescribed warming, as simulated by the GHM and CHM respectively, for each catchment.

CHM projected changes are relatively small $(<5 \%)$, such as for the Xiangxi with the NCAR CCSM3 GCM, where GHM and CHM both project a 38\% change in Q5 relative to baseline. However, in a small number of cases, the differences may be larger, such as with the CCCMA CGCM3.1 simulations of Q95 change for the Liard, which are 22\% (GHM) and $3 \%(\mathrm{CHM})$. Also, there are some GCMs where the two hydrological models simulate changes that are different in sign, e.g., CSIRO MK3.0 (Liard Q5 and Rio Grande Q95) and UKMO HadGEM1 (Liard Q5 and Q95, Rio Grande Q5, Okavango Q5, Xiangxi Q5 and Q95 and Harper's Brook Q5). Secondly, for a given hydrological model, the sign of projected change is not consistent across all seven GCMs for any catchment and indicator (with exception to Q95 for the Liard). For any given hydrological model, the differences between GCMs tend to be large. For instance, for the Okavango, NCAR CCSM3 suggests that the change in Q5 is $+30 \%$ to $+38 \%$ (GHM and CHM respectively) and CSIRO MK3.0 suggests the change is $-40 \%$ to $-30 \%$. Generally, for any given catchment, the difference between the GHM and CHM simulated change for any given GCM is smaller than the difference in projections between the seven GCMs. 


\section{Discussion}

The simulations of response to prescribed global-mean warming with UKMO HadCM3 suggest that the GHM simulates similar changes to the CHM for some hydrological indicators and catchments but substantial differences for others. For instance, the GHM-CHM absolute differences between simulated percentage changes in mean annual runoff are relatively small for the Rio Grande $(<10 \%)$ and Okavango $(<20 \%)$. However, the GHM estimates substantially greater changes in mean annual runoff relative to the CHM for the Liard (>30\%) and lower estimates for the Xiangxi under large increases in global mean air temperature $\left(>4{ }^{\circ} \mathrm{C}\right)$, whilst for Harper's Brook and the Mekong, the GHM and CHM simulate changes that are opposite in sign. Likewise, the GHM-CHM differences in simulated changes of extreme monthly runoff are relatively small $(<10 \%)$ for some catchments (e.g. Q95 for the Xiangxi, Q5 for the Rio Grande) whereas for other catchments, the differences are larger (>30\%; e.g. Q5 for the Xiangxi and Liard), whilst for the Mekong (Q5) and Rio Grande (Q95) the simulated changes are opposite in sign between the two models.

Although GHM-CHM differences are apparent for the UKMO HadCM3 GCM, when $2{ }^{\circ} \mathrm{C}$ prescribed warming across all seven GCMs is considered, there is generally a higher level of agreement, for a given GCM, between the two hydrological models in the sign and magnitude of the mean annual and monthly extreme runoff change for the six catchments. The results imply that the GHM we applied here may be a useful and complimentary tool to the set of CHMs we applied for assessing catchment-scale changes in runoff where ensembles (instead of a single GCM) of GCMs are applied. A potential advantage of this approach is that unless a single CHM is calibrated for each catchment - which can be a time-consuming and demanding exercise - when runoff simulations for several catchments are required, the inherent uncertainty derived from applying different CHMs for each catchment can be removed. For instance, within this study the CHMs applied included SLURP (v. 12.2; Kite et al., 1994), SLURP (v. 12.7; Kite, 1995), Pitman (Hughes et al., 2006), MGB-IPH (Collischonn et al., 2007), AV-SWATX 2005 (Arnold et al., 1998) and Cat-PDM (Arnell, 2003b, 2004b), all of which include their own specific parameterisation schemes. By applying a GHM to several catchments, the parameterisation scheme remains the same for all catchments. Importantly, however, an element of uncertainty would still remain, given that any model parameter is uncertain. Only detailed sensitivity analyses such as multi-method global sensitivity analysis (MMGSA; Cloke et al. 2007) or parameter perturbations (Gosling and Arnell, 2010; Hughes et al., 2010; Arnell, 2010) can demonstrate the sensitivity of simulated runoff to a given parameterisation scheme.

Although the difference in simulated response of annual runoff to $2{ }^{\circ} \mathrm{C}$ prescribed warming between the GHM and CHM are generally small across the 7 GCMs for all catch- ments, the response to $1-6^{\circ} \mathrm{C}$ UKMO HadCM3 forcing differs greatly between GHM and CHM with the Harper's Brook and Mekong catchments. These two catchments are associated with the smallest changes in annual precipitation with climate change of the six catchments investigated - around $-7 \%$ (Harper's Brook) and $+19 \%$ (Mekong) with UKMO HadCM3 $6^{\circ} \mathrm{C}$ (see Fig. 3). The inter-hydrological model differences here can be explained by differences in the seasonal cycle of runoff change simulated by each model - in particular the peak runoff - which are associated with differences in the relative dominance of potential evapotranspiration (PET) over precipitation.

For instance, with Harper's Brook, there are increases in winter precipitation and decreases in summer precipitation with climate change (see Arnell, 2010). However, there are subtle differences between the GHM and CHM in the role of the dominance of increased PET over precipitation with global warming. The CHM simulates a greater reduction in summer (JJA) runoff relative to the $\mathrm{GHM}$ and at $6{ }^{\circ} \mathrm{C}$ prescribed warming; the late-summer runoff simulated by the CHM is almost $0 \%$ of the annual total. Furthermore, the CHM simulates comparatively much greater winter (DJF) runoff increases with climate change than simulated by the GHM. The net effect is that annual runoff decreases with climate change with the GHM whereas it increases slightly with the CHM because of the relative 'strengthening' of its seasonal cycle.

Similarly, for the Mekong, the CHM simulates a greater decrease in peak runoff (August-September) with climate change than the GHM but the slight increases in early season runoff (April-July) simulated by each model are similar. Differences arise, in part, from the application of different algorithms for estimating evapotranspiration. During the calibration of the CHM, Kingston et al. (2010) found that substituting the Penman-Monteith method of estimating PET with a less data-intensive, temperature-based method (Linacre) reduced the overestimation of runoff and improved the representation of seasonal flows by the CHM. Indeed, as shown by Kingston et al. (2009) and Gosling and Arnell (2010), choice of PET algorithm can substantially influence terrestrial water balances. The GHM we applied employs the PenmanMonteith method, so runoff for the Mekong is likely overestimated by the GHM. The net effect for the Mekong is that annual runoff increases with climate change using the GHM but remains relatively unchanged using the CHM. This may also explain why there is such a large discrepancy in simulated high and low monthly flows (Q5 and Q95) between the GHM and CHM for this catchment.

Changes in the seasonal cycle related to the dominance of PET over precipitation by each hydrological model are important and perhaps even more so where the change in annual precipitation with climate change is minor. Furthermore, the nature of the response of runoff to climate change is complex and the common use of mean annual runoff as a measure of the response of hydrological systems to climate 
change is over-simplistic. The analysis presented here and by others (Nóbrega et al., 2010 Hughes et al., 2010; Arnell, 2010; Xu et al., 2010) shows that mean annual runoff can mask considerably greater seasonal variations which are of fundamental importance to water management and our understanding of freshwater availability.

An important result is that even though the magnitudes of simulated changes in mean annual runoff with climate change differ considerably between GCMs, there is consistency in simulated directional shifts of the seasonal cycle. For instance, the increase in spring runoff associated with increased snow-melt and an increase in autumn runoff due to increased precipitation with climate change for the Liard is represented by all seven GCMs, and so is the shift of the peak runoff season from summer (July-August) to autumn (September-October) with climate change for the Xiangxi. This means that for some catchments, whilst there is considerable uncertainty in the magnitude of projected mean annual and monthly extreme runoff change across the 7 GCMs, there is higher confidence in directional shifts of the seasonal cycle. Furthermore, the GHM simulates such changes that are consistent with the CHM, which means despite the generalisations GHMs need to make in order to be run over the global domain, the GHM we applied can be as useful as, and complimentary to, the CHMs we considered for assessments of catchment-scale shifts in the seasonal cycle.

However, it should be noted that whilst the GHM represents the sub-arctic nival regime of the Liard fairly well, compared with the CHM, the GHM simulates peak runoff one month behind the CHM. This is an inherent limitation of the GHM applied here and Gosling and Arnell (2010) have shown that the GHM we applied tends to simulate the peak monthly runoff one month early relative to observations with other sub-arctic catchments such as the Don (central Russia, $378000 \mathrm{~km}^{2}$ ), MacKenzie (central Canada $1570000 \mathrm{~km}^{2}$ ), and $\mathrm{Ob}$ (western Siberia, $2949998 \mathrm{~km}^{2}$ ). Also, the GHM has previously been shown to simulate peak runoff one month ahead of observations for very large catchments such as the Amazon $\left(4640300 \mathrm{~km}^{2}\right)$, Volga $\left(1360000 \mathrm{~km}^{2}\right)$, and $\mathrm{Ob}\left(2949998 \mathrm{~km}^{2}\right)$ because runoff is not routed from one model cell to another (Gosling and Arnell, 2010). The largest catchment considered here, however, is $795000 \mathrm{~km}^{2}$ (Mekong), which is why there is no discrepancy in the months of peak runoff between the GHM and CHM for catchments other than the Liard.

The CHMs applied in this study were calibrated using historical data - see individual papers listed in Table 1 for further details on the calibration methods employed by each CHM. A catchment-specific calibration of the GHM was not performed. Instead, the GHM was calibrated by 'tuning' it to help set parameter values. This involved tests of precipitation datasets and potential evaporation calculations and was done against long-term average runoff and long term average within-year runoff patterns (Arnell, 1999). It is acknowledged that a catchment-specific calibration of the GHM pa- rameters could lead to reductions in the magnitude of some of the GHM-CHM differences presented. For instance, the application of the Linacre method for PET estimation to the GHM instead of Penman-Monteith could reduce the magnitude of the GHM-CHM differences in mean annual runoff and Q5 and Q95 that we present for the Mekong. However, it is important to note that the GHM parameter calibration process is sensitive to uncertainties in the observed data (Biemans et al., 2009).

For any given catchment, the difference in simulated change in mean annual runoff (Fig. 5) or Q5 and Q95 (Fig. 7) between the GHM and CHM for UKMO HadCM $32{ }^{\circ} \mathrm{C}$ prescribed warming is smaller than the difference across the seven GCMs for either the GHM or CHM (Figs. 8 and 10). For instance, with UKMO HadCM $32{ }^{\circ} \mathrm{C}$ prescribed warming, the absolute GHM-CHM differences in mean annual runoff change are $12 \%$ (Liard), 9\% (Mekong), 1\% (Rio Grande), 6\% (Okavango), 10\% (Xiangxi) and 25\% (Harper's Brook), whilst the greatest absolute differences between any two GCMs with $2{ }^{\circ} \mathrm{C}$ prescribed warming for the GHM (CHM) for each catchment respectively are $28 \%(17 \%), 30 \%$ (23\%), $48 \%$ (36\%), 62\% (58\%), 34\% (15\%) and 30\% (31\%). Indeed, an important conclusion to draw from our analysis is that there is little overall consensus in the sign of mean annual and monthly Q5 and Q95 runoff change across all seven GCMs for any of the catchments, even though the GHM and CHM tend to agree on the magnitude and sign of change for any given GCM. The differences in projected changes of mean annual and Q5 and Q95 runoff between the two types of hydrological model are relatively small, in comparison to the range of projections across GCMs. This result supports previous findings that climate modelling structural uncertainty is greater than hydrological modelling uncertainty with simulations of runoff under climate change scenarios (Kay et al., 2009; Blöschl and Montanari, 2010; Kingston and Taylor, 2010; Hughes et al., 2010; Arnell, 2010). This suggests that it may be equally feasible to apply a GHM, as it is to apply a CHM, to explore catchment-scale changes in runoff with climate change from ensembles of currently available GCM projections, where inter-GCM climate projection differences are typically large due to climate modelling uncertainty. However, given that the uncertainty range across the 7 GCMs for the CHM is generally slightly smaller than the range across the GHM, then should advances in climate modelling over the coming decades mean that climate modelling uncertainty is substantially reduced, then the role of hydrological model (and land-surface model) uncertainty will become more important and the application of a CHM over a GHM may be appropriate.

Indeed, it should be noted that whilst Figs. 8, 9 and 10 show that GHM-CHM differences are generally relatively small when a range of GCMs is considered, and that the GHM is able to represent the broad climate change signal that is represented by the CHMs, Figs. 5 and 7 show that for a few catchments and hydrological indicators, when a 
single forcing GCM is considered, the CHM and GHM can disagree substantially. Hence, for a given single GCM, the GHM we applied is no more feasible than a CHM for estimating catchment-scale runoff changes under global warming scenarios.

The substantial GHM-CHM differences observed for some catchments in mean annual runoff, Q5 and Q95 monthly runoff and in the seasonal cycle, has implications for future water management issues, such as, for example, in the planning of dams and reservoirs for dealing with high and low flows. The results suggest larger GHM-CHM differences for indicators of high and low extreme monthly runoff (Q5 and Q95) than for mean annual runoff (although the magnitude of this difference is still smaller than the difference across GCMs) so careful thought should be given in whether to apply a CHM or GHM when measures of extreme hydrological behaviour are sought. This, however, in unsurprising given that extremes of hydrological behaviour are notoriously difficult to simulate. We postulate that if another CHM were included for each catchment, the difference between the new CHM and the CHM presented in this study, in simulated changes in Q5 and Q95 with climate change, might be comparable to that of the differences between GHM and CHM presented here. Indeed, in a discussion of the role of uncertainty in climate change impacts assessment and hydrology, Blöschl and Montanari (2010) suggest that when two experts estimate the 100-year flood in a small ungauged catchment, chances are that their estimates are very different. A recent inter-model comparison confirms the case in point (Ludwig et al., 2009), suggesting that the difference in simulated discharge under climate change scenarios for a 10-year flood event and given catchment between hydrological models of different complexity may be over $200 \%$.

The discrepancy in sign of simulated change across the 7 GCMs has implications for policy- and decision-making. Whilst one should be cautious with results based on projections from a single GCM because mistaken management decisions may follow (Nóbrega et al., 2010), decision-makers are faced with a challenging prospect when approached with a range of projections from several GCMs that are different in sign. In the case of the Liard, where 6 of 7 GCMs suggest very little change or an increase in runoff with climate change, the GCM that suggests a decrease in annual runoff may arguably be considered as an outlier (Todd et al., 2010). However, where around half the GCMs suggest a substantial increase in annual runoff with climate change and the other half a substantial decrease (e.g. the Mekong and Rio Grande), then the decision-making process is more complex. Summary statistics such as the ensemble-mean are inappropriate with such projections because "the mean of equal increases and decreases is no change".

A key conclusion is that climate model uncertainty dominates hydrological model uncertainty. However, it is acknowledged that this conclusion is based on the prior uncertainty assigned to both climate and hydrological models.
Moreover, we have not sampled downscaling uncertainty, emissions uncertainty, and hydrological model parameter uncertainty (see Fig. 1). Therefore, we are likely underestimating the magnitude of climate and hydrological uncertainty in our analysis. Given the constraints of computational resources, we considered seven climate models and two hydrological models for each catchment. It can be argued that the application of seven climate models presents a reasonable representation of climate model structural uncertainty, given that previous climate change hydrological impact assessments have tended to apply a similar or lower number of climate models (Arnell et al., 2011; Hayashi et al., 2010; Prudhomme et al., 2003). The prior uncertainty from climate model structural uncertainty could be reduced by comparing GCM simulations of baseline climate with observations. Such considerations have led to the calculation of performance metrics for GCMs, such as ranking them according to a measure of relative error (Gleckler et al., 2008). Forming a single index of model performance, however, can be misleading in that it hides a more complex picture of the relative merits of different models. Furthermore, for one specific region, Chiew et al. (2009) concluded that there was no clear difference in rainfall projections between the "better" and "poorer" 23 GCMs included in the CMIP3 archive (7 of which we applied here) based on their abilities to reproduce observed historical rainfall. Therefore in their analysis, using only the better GCMs or weights to favour the better GCMs gave similar runoff impact assessment results as the use of all the 23 GCMs. Moreover, on a conceptual level, it has been argued that, because of deep and structural uncertainty, it is not appropriate to seek to estimate the relative weight of different GCMs, and to do so would lead to significant over-interpretation of model-based scenarios (Stainforth et al., 2007): all models are only partial representations of a complex world, and miss important processes. For these reasons, in the present analysis, we assumed that all the GCMs are equally credible, although they are not completely independent.

The computational resources required to perform multiple GHM simulations are relatively small compared with those required to run multiple CHMs because in previous work ClimGen was integrated with the GHM and adapted to run by high throughput computing (HTC) on the University of Reading Campus Grid, which reduced simulation time by a factor of over 80 relative to running on a single compute node (see Gosling et al., 2010). A more thorough consideration of downscaling uncertainty would apply climate projections from regional climate models (RCMs), which have been dynamically downscaled, and/or a range of different statistical downscaling algorithms other than that included in ClimGen (e.g. see Maraun et al., 2010). However, this would effectively at least double the computing and time resources required from what was used in the present analysis.

A more thorough consideration of hydrological model uncertainty would explore (1) hydrological model parameter 
perturbations, and (2) the application of several CHMs for each catchment. However, this would be demanding in terms of computational and human resources. For instance, to address the latter suggestion above, each CHM (SLURP, SWAT, etc.) would need to be calibrated for each individual catchment (Liard, Mekong etc.) and would then involve performing $216 \mathrm{CHM}$ simulations $(6 \mathrm{CHMs} \times 6$ catchments $\times 6$ increases in global-mean air temperature) for a single GCM pattern. As such, a computer cluster with around 216 nodes would be ideal, but each CHM would need to be adapted for running by HTC. This is not straightforward; see Gosling et al. (2010) for a detailed discussion on the issues regarding adapting a hydrological model to run by HTC. To address the former suggestion, Multi-Method Global Sensitivity Analysis (MMGSA; Cloke et al., 2007) presents a method for systematically perturbing all model parameters systematically but again, the extensive computing resources required for this precluded such an analysis here. Moreover, each CHM and GHM will include different parameters, so a like-withlike comparison is not straightforward. Nevertheless, Arnell (2010) demonstrates that the uncertainty associated with 100 CHM model parameter sets is vastly smaller than the uncertainty across 21 GCM climate projections, which supports our conclusion that climate model uncertainty dominates hydrological model uncertainty. Moreover, evidence from other climate change impact assessment sectors (e.g. agriculture; Challinor et al., 2009) suggests that climate model uncertainty is effectively damped once other non-climatic uncertainties, such as decision-making processes or socioeconomic uncertainties are considered, in a wider decisionmaking framework.

Our analysis demonstrates that the GHM is able to represent the broad climate change signal that is represented by the CHMs, for each catchment. Therefore where future climate change impacts assessments seek to quantify and assess the range of hydrological projections across an ensemble of GCMs, it may be as equally feasible to apply a GHM as it is to apply a CHM to explore catchment-scale changes in runoff with global warming. However, in the present analysis, we only considered only one GHM, Mac-PDM.09 (Gosling and Arnell, 2010). Recent work highlights that there is uncertainty across different GHMs in the simulation of runoff (Haddeland et al., 2011), so it can not be assumed that all GHMs will perform in the same way as the GHM presented here.

\section{Conclusions}

We have presented a comparative analysis of projected impacts of global warming on river runoff from a GHM (MacPDM.09; Gosling and Arnell, 2010) and a set of catchmentspecific CHMs for six catchments, which are global in coverage and feature strong contrasts in spatial scale as well as climatic and developmental conditions. For some catchments and simulated hydrological indicators, particularly with indicators of high and low extreme monthly runoff, the GHMCHM difference for a single GCM and climate forcing can be substantial. This highlights firstly, that it is important to consider more than only the simulated mean annual runoff when comparing different hydrological models, and secondly, that for a given single GCM, the GHM we applied is no more feasible than a CHM for estimating catchment-scale runoff changes under global warming scenarios. Whilst for some catchments there is considerable uncertainty in the magnitude of projected mean annual runoff and Q5 and Q95 change across the seven GCMs, there is higher confidence in directional shifts of the seasonal cycle, such as increases in spring and autumn runoff with the Liard catchment, although the GHM does, for some catchments, estimate the month of peak or low runoff one or two months ahead or behind the CHM.

Perhaps the most important conclusion to draw from our analysis is that the differences in projected changes of mean annual as well as high (Q5) and low (Q95) monthly runoff between the two types of hydrological model are generally relatively small in comparison to the range of projections across the seven GCMs. For example, with UKMO HadCM3 $2{ }^{\circ} \mathrm{C}$ prescribed warming, the absolute GHM-CHM differences in mean annual runoff change are 12\% (Liard), 9\% (Mekong), 1\% (Rio Grande), 6\% (Okavango), 10\% (Xiangxi) and 25\% (Harper's Brook), whilst the greatest absolute differences between any two GCMs with $2{ }^{\circ} \mathrm{C}$ prescribed warming for the GHM (CHM) for each catchment respectively are $28 \%$ (17\%), $30 \%$ (23\%), $48 \%$ (36\%), $62 \%(58 \%)$, $34 \%(15 \%)$ and $30 \%(31 \%)$. This implies that climate model structural uncertainty is greater than the uncertainty associated with the type of hydrological model applied. Therefore, where future climate change impacts assessments seek to quantify and assess the range of hydrological projections across an ensemble of GCMs, it may be as equally feasible to apply a GHM (Mac-PDM.09 here) as it is to apply a CHM to explore catchment-scale changes in runoff with global warming. Given that there is a growing acceptance that climate change impacts assessments should consider the range of uncertainty inherent in the currently available set of GCMs available to the modelling community, this is a poignant finding. However, although the GHM is able to represent the broad climate change signal that is represented by the CHMs, across seven GCMs, when a single forcing GCM is considered, the CHM and GHM can disagree substantially, for a few catchments and hydrological indicators, especially with indicators of extreme monthly runoff. These differences have implications for future water management issues, such as, for example, in the planning of dams and reservoirs for dealing with high and low flows. As such, our analysis suggests that given the choice, there is no evidence to suggest that the application of a GHM would be more favourable than the application of a CHM, for the estimation of changes in catchment-scale runoff under climate change scenarios. 
Acknowledgements. This work was supported by a grant from the Natural Environment Research Council (NERC), under the QUEST programme (grant no. NE/E001890/1). Thank you to the following for performing the catchment-scale hydrological model simulations of runoff, for the Liard (Robin Thorne, School of Geography and Earth Sciences, McMaster University, Canada), Mekong (Daniel G. Kingston, Department of Geography, University of Otago, New Zealand), Okavango (Denis A. Hughes, Institute for Water Research, Rhodes University, South Africa), Rio Grande (Márcio T. Nóbrega, Walter Collischonn, Carlos E. M. Tucci and Adriano R. da Paz, Instituto de Pesquisas Hidráulicas, Universidade Federal do Rio Grande do Sul, Brazil) and Xiangxi (Hongmei $\mathrm{Xu}$, Laboratory for Climate Studies of China Meteorological Administration, National Climate Center, China). Thank you to Dan Bretherton (ESSC, University of Reading, UK), University of Reading IT Services and the entire University of Reading Campus Grid team for their support in setting-up Mac-PDM.09 to run by high throughput computing on the University of Reading Campus Grid. The climate model projections were taken from the WCRP CMIP3 dataset (http://www-pcmdi.llnl.gov/ipcc/about_ipcc.php). ClimGen was developed by Tim Osborn at the Climatic Research Unit (CRU) at the University of East Anglia (UEA), UK. Hannah Cloke (Department of Geography, King's College London) and an anonymous reviewer are thanked for their very helpful comments on a previous version of the manuscript.

Edited by: J. Vrugt

\section{References}

Abbott, M. B. and Refsgaard, J. C., Distributed Hydrological Modeling, Kluwer Academic Publishers, Dordrecht, 1996.

Alcamo, J., Doll, P., Henrichs, T., Kaspar, F., Lehner, B., Rosch, T., and Siebert, S.: Global estimates of water withdrawals and availability under current and future "business-as usual" conditions, Hydrol. Sci. J., 48, 339-348, 2003.

Arnell, N. W.: A simple water balance model for the simulation of streamflow over a large geographic domain, J. Hydrol., 217, 314-335, 1999.

Arnell, N. W.: Effects of IPCC SRES* emissions scenarios on river runoff: a global perspective, Hydrol. Earth Syst. Sci., 7, 619641, doi:10.5194/hess-7-619-2003, 2003a.

Arnell, N. W.: Relative effects of multi-decadal climatic variability and changes in the mean and variability of climate due to global warming: future streamflows in Britain, J. Hydrol., 270, 195213, 2003b.

Arnell, N. W.: Climate change and global water resources: SRES emissions and socioeconomic scenarios, Global Environ. Chang., 14, 31-52, 2004a.

Arnell, N. W.: Climate change impacts on river flows in Britain: the UKCIP02 scenarios. J. Chart. Inst. Water E., 18, 112-117, 2004b.

Arnell, N. W.: The relationship between climate forcing and hydrological response in UK catchments, Hydrol. Earth Syst. Sci. Discuss., 7, 7633-7667, doi:10.5194/hessd-7-7633-2010, 2010.

Arnell, N. W., van Vuuren, D. P., and Isaac, M.: The implications of climate policy for the impacts of climate change on global water resources, Global Environ. Change, in press, 2011
Arnold, J. G., Srinivasan, R., Muttiah, R. S., and Williams, J. R.: Large area hydrologic modeling and assessment part I: model development, J. Amer. Wat. Res. Assoc. 34, 73-89, 1998.

Bates, B. C., Kundzewicz, Z. W., Wu, S., and Palutikof, J. P. (Eds): Climate Change and Water, Technical Paper of the Intergovernmental Panel for Climate Change, IPCC Secretariat, Geneva, Switzerland, 2008.

Beven, K. J.: Rainfall-Runoff Modelling: The Primer, Wiley, Chichester, UK, 2001.

Biemans, H., Hutjes, R. W. A., Kabat, P., Strengers, B. J., Gerten, D., Rost, S.: Effects of precipitation uncertainty on discharge calculations for main river basins, J. Hydrometeorol., 10, 10111025, 2009.

Blöschl, G. and Montanari, A.: Climate change impacts - throwing the dice? Hydrol. Process., 24, 374-381, doi:10.1002/hyp.7574, 2010.

Boyle, D. P., Gupta, H. V., Sorooshian, S., Koren, V., Zhang, Z., and Smith, M.: Toward Improved Streamflow Forecasts: Value of Semidistributed Modeling, Water Resour. Res., 37, 2749-2759, 2001.

Breuer, L., Huisman, J. A., Willems, P., Bormann, H., Bronstert, A., Croke, B. F. W., Frede, H. -G., Graff, T., Hubrechts, L., Jakeman, A. J., Kite, G., Lanini, J., Leavesley, G., Lettenmaier, D. P., Lindstrom, G., Seibert, J., Sivapalan, M., and Viney, N. R.: Assessing the impact of land use change on hydrology by ensemble modeling (LUCHEM). I: Model intercomparison with current land use, Adva. Water Resour., 32, 129-146, 2009.

Carpenter, T. M. and Georgakakos, K. P.: Intercomparison of lumped versus distributed hydrologic model ensemble simulations on operational forecast scales, J. Hydrol., 329, 174-185, 2006.

Challinor, A. J., Wheeler, T., Hemming, D., and Upadhyaya, H. D.: Ensemble yield simulations: crop and climate uncertainties, sensitivity to temperature and genotypic adaptation to climate change, Clim. Res., 38, 117-127, 2009.

Chiew, F. H. S., Teng, J., Vaze, J., and Kirono, D. G. C.: Influence of global climate model selection on runoff impact assessment, J. Hydrol., 379, 172-180, 2009.

Cloke, H. L., Pappenberger, F., and Renaud, J-P.: Multi-method global sensitivity analysis (MMGSA) for modelling floodplain hydrological processes, Hydrol. Proc., 22, 1660-1674, 2007

Collischonn, W., Allasia, D. G., Silva, B. C., and Tucci, C. E. M.: The MGB-IPH model for large-scale rainfall-runoff modelling, Hydrol. Sci. J., 52, 878-895, 2007

Cuo, L., Lettenmaier, D. P., Mattheussen, B. V., Storck, P., and Wiley, M.: Hydrologic prediction for urban watersheds with the Distributed Hydrology-Soil-Vegetation Model, Hydrol. Proc., 22, 4205-4213, 2008.

de Fries, R. S., Hansen, M., Townshend, J. R. G., and Sholberg, R.: Global land cover classification at $8 \mathrm{~km}$ spatial resolution: the use of training data derived from Landsat imagery in decision tree classifiers., Int. J. Remote Sens., 19, 3141-3168, 1998

Döll, P., Kaspar, F., and Lehner, B.: A global hydrological model for deriving water availability indicators: model tuning and validation, J. Hydrol., 270, 105-134, 2003

FAO: Digital soil map of the World (CD-ROM), FAO, Rome, 1995.

Gleckler, P. J., Taylor, K. E., and Doutriaux, C.: Performance metrics for climate models, J. Geophys. Res., 113, D06104, doi:10.1029/2007JD008972, 2008. 
Gosling, S. N. and Arnell, N. W.: Simulating current global river runoff with a global hydrological model: model revisions, validation and sensitivity analysis, Hydrol. Proc., doi:10.1002/hyp.7727, 2010.

Gosling, S. N., Bretherton, D., Haines, K., and Arnell, N. W: Global Hydrology Modelling and Uncertainty: Running Multiple Ensembles with a campus grid, Phil. Trans. Royal Soc. A, 368, 1$17,2010$.

Gosling, S. N., Lowe, J. A. McGregor, G. R., Pelling, M., and Malamud, B. D.: Associations between elevated atmospheric temperature and human mortality: a critical review of the literature, Clim. Change, 92, 299-341, 2009.

Haddeland, I., Clark, C., Franssen, W., Ludwig, F., Voß, F., Arnell, N. W., Bertrand, N., Best, S., Folwell, S., Gerten, D., Gomes, S., Gosling, S. N., Hagemann, S., Hanasaki, N., Harding, R., Heinke, J., Kabat, P., Koirala, S., Polcher, J., Stacke, T., Viterbo, P., Weedon, G., and Yeh, P.: Multi-Model Estimate of the Global Water Balance: Setup and First Results, J. Hydrometeorol., in review, 2011.

Hayashi, A., Akimoto, K., Sano, F., Mori, S., and Tomoda, T.: Evaluation of global warming impacts for different levels of stabilisation as a step toward determination of the long-term stabilisation target, Clim. Change, 98, 87-112, 2010.

Henriksen, H. J., Troldborg, L., Højberg, A. J., and Refsgaard, J. C.: Assessment of exploitable groundwater resources of Denmark by use of ensemble resource indicators and a numerical groundwater - surface water model, J. Hydrol., 348, 224-240, 2008.

Hughes, D. A., Andersson, L., Wilk, J., and Savenije, H. H. G.: Regional calibration of the Pitman model for the Okavango River, J. Hydrol., 331, 30-42, 2006.

Hughes, D. A., Kingston, D. G., and Todd, M. C.: Uncertainty in water resources availability in the Okavango River Basin as a result of climate change, Hydrol. Earth Syst. Sci. Discuss., 7, 5737-5768, doi:10.5194/hessd-7-5737-2010, 2010.

Jones, R. N., Chiew, F. H. S., Boughton, W. C., and Zhang, L.: Estimating the sensitivity of mean annual runoff to climate change using selected hydrological models, Adv. Water Res., 29, 14191429, 2006.

Kay, A. L., Davies, H. N., Bell, V. A., and Jones, R. G.: Comparison of uncertainty sources for climate change impacts: flood frequency in England, Clim. Change, 92, 41-63, 2009

Kingston, D. G. and Taylor, R. G.: Projected impact of climate change on groundwater and stormflow in a humid, tropical catchment in the Ugandan Upper Nile Basin, Hydrol. Earth Syst. Sci., 7, 1913-1944, 2010, http://www.hydrol-earth-syst-sci.net/7/1913/2010/.

Kingston, D. G., Thompson, J. R., and Kite, G.: Uncertainty in climate change projections of discharge for the Mekong River Basin, Hydrol. Earth Syst. Sci. Discuss., 7, 5991-6024, doi:10.5194/hessd-7-5991-2010, 2010.

Kingston, D. G., Todd, M. C., Taylor, R. G., Thompson, J. R., and Arnell, N. W.: Uncertainty in the estimation of potential evapotranspiration under climate change, Geophys. Res. Lett., 36, L20403, doi:10.1029/2009GL040267, 2009.

Kite, G. W.: The SLURP model, in: Computer Models of Watershed Hydrology, edited by: Singh, V. P., Water Resources Publications, Colorado, 521-562, 1995.

Kite, G. W., Dalton, A., and Dion, A.: Simulation of streamflow in a macroscale watershed using general circulation model data,
Water Resour. Res., 30, 1547-1559, 1994.

Kundzewicz, Z. W., Mata, L. J., Arnell, N. W., Döll, P., Kabat, P., Jiménez, B., Miller, K. A., Oki, T., Sen Z., and Shiklomanov, I. A.: Freshwater resources and their management. Climate Change 2007: Impacts, Adaptation and Vulnerability. Contribution of Working Group II to the Fourth Assessment Report of the Intergovernmental Panel on Climate Change, edited by: Parry, M. L., Canziani, O. F., Palutikof, J. P., van der Linden, P. J., and Hanson, C. E., Cambridge University Press, Cambridge, UK, 173-210, 2007.

Ludwig, R., May, I., Turcotte, R., Vescovi, L., Braun, M., Cyr, J.F., Fortin, L. G., Chaumont, D., Biner, S., Chartier, I., Caya, D., and Mauser, W.: The role of hydrological model complexity and uncertainty in climate change impact assessment, Adv. Geosci., 21, 63-71, 2009,

http://www.adv-geosci.net/21/63/2009/.

Majone, B., Bertagnoli, A., and Bellin, A.: Non-linear runoff generation model in small Alpine catchments, J. Hydrol., 385, 300312, 2010.

Maraun, D., Wetterhall, F., Ireson, A. M., Chandler, R. E., Kendon, E. J., Widmann, M., Brienen, S., Rust, H. W., Sauter, T., Themeßl, M., Venema, V. K. C., Chun, K. P., Goodess, C. M., Jones, R. G., Onof, C., Vrac, M., and Thiele-Eich, I.: Precipitation downscaling under climate change: Recent developments to bridge the gap between dynamical models and the end user. Rev. Geophys., 48, RG3003, doi:10.1029/2009RG000314, 2010.

Meehl, G. A., Covey, C., Delworth, T., Latif, M., McAvney, B., Mitchell, J. F. B., Stouffer, R. J., and Taylor, K. E.: TheWCRP CMIP3 multimodel dataset: A new era in climate change research, B. Am. Meteorol. Soc., 88, 1383-1394, 2007.

Mitchell, T. D.: Pattern Scaling: An Examination of the Accuracy of the Technique for Describing Future Climates, Clim. Change, 60, 217-242, 2003.

Mitchell, T. D. and Jones, P. D.: An improved method of constructing a database of monthly climate observations and associated high-resolution grids, Int. J. Climatol., 25, 693-712, 2005.

Nash, J. E. and Sutcliffe, J. V.: River flow forecasting through conceptual models: Part 1 - a discussion of principles, J. Hydrol., 10, 282-290, 1970.

Nóbrega, M. T., Collischonn, W., Tucci, C. E. M., and Paz, A. R.: Uncertainty in climate change impacts on water resources in the Rio Grande Basin, Brazil, Hydrol. Earth Syst. Sci. Discuss., 7, 6099-6128, doi:10.5194/hessd-7-6099-2010, 2010.

Prudhomme, C., Jakob, D., and Svensson, C.: Uncertainty and climate change impact on the flood regime of small UK catchments, J. Hydrol., 277, 1-23, 2003.

Refsgaard, J. C. and Knudsen, J.: Operational validation and intercomparison of different types of hydrological models, Water Resour. Res., 32, 2189-2202, 1996.

Stainforth, A., Aina, T., Christensen, C., Collins, M., Faull, N., Frame, D. J., Kettleborough, J. A., Knight, S., Martin, A., Murphy, J. M., Piani, C., Sexton, D., Smith, L. A., Spicer, R. A., Thorpe, A. J., and Allen, M. R.: Uncertainty in predictions of the climate response to rising levels of greenhouse gases, Nature, 433, 403-406, 2005.

Stainforth, D. A., Allen, M. R., Tredger, E. R., and Smith, L. A.: Con?dence, uncertainty and decision-support relevance in climate prediction, Philos. T. R. Soc. A, 365, 2145-2161, 2007.

Thorne, R.: Uncertainty in the impacts of projected climate 
change on the hydrology of a subarctic environment: Liard River Basin, Hydrol. Earth Syst. Sci. Discuss., 7, 3129-3157, doi:10.5194/hessd-7-3129-2010, 2010.

Todd, M. C., Taylor, R. G., Osborne, T., Kingston, D., Arnell, N. W., and Gosling, S. N.: Quantifying the impact of climate change on water resources at the basin scale on five continents - a unified approach, Hydrol. Earth Syst. Sci. Discuss., 7, 7485-7519, doi:10.5194/hessd-7-7485-2010, 2010.
$\mathrm{Xu}, \mathrm{H}$. , Taylor, R. G., and Xu, Y.: Quantifying uncertainty in the impacts of climate change on river discharge in sub-catchments of the River Yangtze and Yellow Basins, China, Hydrol. Earth Syst. Sci. Discuss., 7, 6823-6850, doi:10.5194/hessd-7-68232010, 2010. 